\section{Lauren Simms}

Dominican House of Studies, Washington, DC Isimms@smu.edu

ORCiD: 0000-0002-3137-2240

DOI: http://dx.doi.org/10.12775/BPTh.2020.009
Biblica

et

Patristica

Thoruniensia

13 (2020) 2: 199-215

ISSN (print) 1689-5150

ISSN (online) 2450-7059

\title{
The Ordination and the Exercise of the Priesthood of the Baptized in Augustine, Chrysostom, and Aquinas*
}

\begin{abstract}
Whereas Augustine, Chrysostom, and Aquinas are all cited as sources for the doctrine of the priesthood of the baptized in Lumen gentium, not one left behind a treatise devoted to the topic. The author of this article provides a survey of the baptismal priesthood in the thought of the three doctors with respect to two theological concepts: (1) the Christian's participation in the priesthood of Christ through incorporation into his Body, or their ordination, and (2) the exercise for which the baptismal priesthood is ordained, namely to worship God both in the liturgy and through a life of virtue. The author aims both to illuminate the thought of each theologian and to show the concordance of Aquinas's thought with that of his predecessors.
\end{abstract}

Keywords: Priesthood of the Baptized; Baptism; Augustine; John Chrysostom; Thomas Aquinas; Sacrifice; Charity; Biblical Thomism.

\section{Introduction}

7 he priesthood of the baptized is among the rich biblical themes reclaimed 1 in the return ad fontes of the nineteenth and twentieth centuries. Indeed, the baptismal priesthood became a fundamental point of reflection during the

* As an exercise in Biblical Thomism, this paper seeks to understand Thomas Aquinas as a scholar who was, above all, a master in Sacred Scripture (magister in sacra pagina). Aquinas understood Scripture as detailing God's descent toward and redemption of humanity, while, on the other hand, theology described the ascent back to God that was nurtured and propelled by all that the Scriptures reveal. Because of their proximity to the apostolic period, the writings of the Church Fathers-including Augustine and Chrysostom-offer explanations of all that is made manifest in the Bible. Further, the Fathers authoritatively demonstrate how these mysteries have been received and interepreted by the Church.

For deeper reflections on the efforts of scholars of Biblical Thomism, see P. Roszak and J. Vijgen, eds., Reading Sacred Scripture with Thomas Aquinas: Hermeneutical Tools, Theological Questions, and New Perspectives, Turnhout, Belgium 2015. 
Second Vatican Council and the magisterial documents that followed, where it serves as the basis of the teaching on the active participation in the liturgy found in Sacrosanctum Concilium and of Lumen gentium's articulation of the laity's position in the Church.

Interestingly, whereas Augustine, John Chrysostom, and Thomas Aquinas are all referenced in the sections treating the common priesthood, none of them penned a systematic treatment of the theme. Nevertheless, in the works of these three Doctors of the Church, one can identify two recurring, related concepts regarding the baptismal priesthood; these same themes are highlighted in Lumen gentium, namely: (1) the Christian's participation in the priesthood of Christ through incorporation into his Body, or their ordination, ${ }^{1}$ and (2) the exercise for which the baptismal priesthood is ordained, namely to worship God both in the liturgy and through a life of virtue.

In the first part of this paper, I will briefly survey the notions of the ordination to the priesthood of the baptized in the thought of Augustine, Chrysostom, and Aquinas. In the second part, I will highlight key characteristics of the acts proper to the baptismal priesthood. I aim to expose each thinker's understanding of the priesthood of the faithful, and, by examining each thinker successively, I hope to demonstrate the correspondence of Aquinas's theology with the thinking of his predecessors.

\section{A Note Regarding Aquinas's Reception of Augustine and Chrysostom}

There is no doubt that Aquinas regarded both St. Augustine (d. 430) and St. John Chrysostom (d. 407) as auctoritates, who granted to both the title of expositores sacrae scripturae. ${ }^{2}$ The weight of Augustine's authority for St. Thomas is substantiated in that the Doctor gratiae is cited over eleven thousand times in the Corpus Thomisticus. Marie-Dominique Chenu rightly presents Aquinas as one "genuinely reared in Augustine," who proved himself to be Augustine's "faithful disciple" and interpreter, "both in theological doctrine and in the qual-

1 A note about using the term "ordination" in regard to the baptismal priesthood: Although the English rendering seems strange, particularly as it is usually reserved to indicate the conferral of the sacrament of Holy Orders, Aquinas speaks of the believer as being ordained (ordinandum) to particular ends by the sacramental character. Thomas Aquinas, $S T$ III, q. 63 , a. 3 .

2 Thomas Aquinas, ST I-II, q. 69, a. 2c. 
ity of his spirituality." 3 On the other hand, of the more than one thousand works attributed to St. John Chrysostom, scholars can only affirm with certainty that Aquinas had access to the Latin translations of Chrysostom's homilies on Matthew, John, and Genesis, ${ }^{4}$ as well as other smaller works, such as On the Compunction of the Heart. ${ }^{5}$ Although Aquinas only cites Chrysostom about a third of the number of times that he cites Augustine-still some 3,600 times throughout his corpus-his respect of the Greek Father was so great that Aquinas is purported to have declared that he would prefer "with greater pleasure" to have Chrysostom's Commentary on Matthew rather than possess the entire city of Paris. ${ }^{6}$

\section{Part 1: The Ordination to the Baptismal Priesthood through Incorporation into the Christ}

Having established in general terms Aquinas's familiarity with the doctrine of Augustine and Chrysostom, I now turn to an examination of the concordance of their theological doctrine with respect to the priesthood of the baptized. A key theme among all three thinkers-one which is duly highlighted in Lumen gentium-is participation in the priesthood of the faithful through incorporation into Christ. This theme is fundamentally biblical, spread in the Gospels, the Pauline letters, Hebrews, the first Petrine epistle, and the Book of Revelation. As theologians intimately engaged with Sacred Scripture, the three doctors of the Church all considered the great grace bestowed in the sacrament of baptism as the manner by which the believer is incorporated into the Body of Christ. They are clear: it is through the sacramental washing, and the anointing with the Holy Spirit that accompanies it, that the faithful are ordained to share in Christ's priesthood.

\subsection{Ordination in Augustine: Incorporation as a member of the Unus Christus}

Augustine recognized that the baptismal priesthood is an extension of Christ's own priesthood, which the faithful participate by means of their membership in the Mystical Body. The Bishop of Hippo frequently marvels at the mystery

3 M.-D. Chenu, Toward Understanding Saint Thomas, 127.

4 L. Elders, Thomas Aquinas and His Predecessors, 157-158.

5 De Compunctione Cordis is cited in ST III, q. 1, a. 3, obj. 3.

6 William of Tocco, Ystoria sancti Thome de Aquino, 42. 
of man's incorporation into Christ, instructing his flock, "when you have been baptized, then you have been born members"7 of Christ's Body, for "no one becomes a member of Christ, except by baptism in Christ or by death for Christ." ${ }^{8}$ On Augustine's account, the believer, made a member of Christ, is so intimately joined to his head that Augustine does not hesitate to assert that "we are Christ-both him and us," for "the Head and the body is the one Christ." 10

The body shares in everything which is proper to the Head-including the Head's anointing as priest-through the unity which the body has with its Head. Augustine drew on the biblical type of Aaron in Psalm 133, whose priestly anointing prefigured the anointing of Christ as priest, prophet, and king. Just as the oil flowed from Aaron's head to his beard and garments, Christ's anointing is shared by all members of his Body. Augustine expounds, "just as we call all Christians 'christs' by virtue of their mystical anointing, so we call all Christians 'priests' (sacerdotes) because they are all members of the one priest."11 Elsewhere, he explains that "the priesthood of the Jews was a figure of the royal priesthood to come, which is in the Church, and by which all who belong to the body of Christ, the true and highest Priest, are consecrated. But now all are anointed," 12 because all are members of the unus Christus, who is the Anointed One. For Augustine, then, it is by the believer's incorporation into the Church through baptism that the Christian shares in everything that Christ is in his humanity, including his priestly mediatorship.

\subsection{John Chrysostom: Knit into Christ and Sealed in his Spirit}

Like Augustine, Chrysostom has a rich understanding of the believer's ordination to the priesthood through baptism. Through this sacrament, the Christian comes to share in everything that Christ is, including the offices of priest, prophet, and king. Speaking as Patriarch of Constantinople, he instructed his

7 Augustine, Sermons, 72/A, 289.

8 Augustine, an. et or. I, 9, 10 (PL 44:480).

9 Augustine, en. Ps. 142.3. (PL 36:1847).

10 Augustine, Jo. ev. tr. 108.5 (PL 35:1916).

11 Augustine, civ. Dei, XX, 10 (PL 41:676).

12 Augustine, q. Ev. II, 40.3 (PL 35:1355): Sacerdotium vero iudeorum nemo fere fidelium dubitat figuram fuisse futuri sacerdotii regalis, quod est in ecclesia, quo consecrantur omnes pertinentes ad corpus christi, summi et ueri principis sacerdotum. nam nunc et omnes unguntur, quod tunc regibus tantum et sacerdotibus fiebat; et quod ait petrus ad christianum populum scribens: regale sacerdotium, utrumque nomen illi populo conuenire declarauit, quo illa unctio pertinebat. [Translation mine]. 
flock that just as Christ is priest, prophet, and king, so you also are made king and priest and prophet in the Baptismal font; a king, having dashed to earth all the deeds of wickedness and slain your sins; a priest, in that you offer yourself to God ... a prophet ... being inspired of God and sealed" with the Holy Spirit. ${ }^{13}$ Chrysostom further marvels that Christians are so intimately associated with Christ at the baptismal font as to be made sons in the one Son at the baptismal font, proclaiming, "look how He has knit us into Himself!"14

Chrysostom also highlights the action of the Holy Spirit as integral to the ordination of the baptismal priesthood. It is the Holy Spirit, received at baptism, who grants them a participation in Christ's own anointing. The Spirit makes them "at once prophets and priests and kings, for in old times these three sorts were anointed. But we have now not one of these dignities, but all three preeminently. For we ... are made priests by offering our bodies for a sacrifice, for, [as Paul says], 'present your members a living sacrifice unto God."'15 It is clear that, for Chrysostom, both the baptismal washing and the graces of the Holy Spirit poured out in the sacrament constitute the believer as a baptized priest.

\subsection{Aquinas: Sharing in the Priesthood of Christ, their Head by Baptismal Character}

Like Augustine and Chrysostom before him, Aquinas also attributes the title of priest to the Christian because of his incorporation into Christ in baptism. In other words, because Christ is anointed priest, and by baptism, the believer shares in Christ's anointing, the baptized is himself anointed priest.

Aquinas's rich understanding of the Christian's priesthood is rooted in his careful reading of Sacred Scripture and of the writings of the Church Fathers. ${ }^{16}$ Indeed, because Thomas Aquinas was himself a magister in sacra pagina, ${ }^{17}$ it is impossible to detach his vision of Christ's priesthood-and our participation in it-as articulated in his mature, systematic works from his exegetical

13 John Chrysostom, Hom. in II Cor. 3.7 (PG 61, 417-418).

14 John Chrysostom, Hom. in Col. 4.3 (PG 62, 327).

15 John Chrysostom, Hom. in II Cor. 3.5 (PG 61, 411).

16 G. Berceville, "Le sacerdoce du Christ," p. 144.

17 P. Rosak and J. Vijgen, Reading Sacred Scripture with Thomas Aquinas, p. vii. Roszak and Vijgen go on to explain that Aquinas' theology "as a master in Sacred Scripture consists in explaining and exploring the meanings of the biblical text based on a hermeneutic model that leads to a theological exegesis and ultimately to an ecclesial application." p. viii. 
commentaries on the Psalms, ${ }^{18}$ Jeremiah, ${ }^{19}$ and the Pauline epistles, including Hebrews ${ }^{20}$ which Aquinas attributed to St. Paul. Further, one cannot deny the influence of the Patristic sources Aquinas encountered in the various glossae he read and in the process of composing the Catena Aurea. ${ }^{21}$ For Thomas, the writings of the Fathers were composed "under the assistance of the same Holy Spirit who inspired the authors of the Bible. For this reason, the Fathers are a source of Christian doctrine in so far as they present and explain what is contained in the Bible and their teachings have been received by the Church." 22

The opinions of the Church Fathers appear on every page of the Summa theologiae, Thomas's most mature treatise. Yet, therein, one finds only the basic framework for the Angelic Doctor's understanding of the priesthood of the baptized, treated in the articles concerning Christ's headship (III q. 8), his priesthood (III q. 22), and sacramental character (III q. 63). In these questions, Aquinas presents a vision of the Christian who, through incorporation into Christ's Mystical Body by baptism, shares in all Christ their Head has received. Thomas affirms that all have received grace only on account of Christ's grace. ${ }^{23}$ As was seen in both Augustine and Chrysostom, Aquinas holds that, in being reborn as sons of God through the baptismal washing, the faithful are reformed in the image of the Son and "likened [to Christ] by reason of the sacramental characters, which are nothing else than certain participations of Christ's Priesthood." 24

The influence of the Fathers permeates Thomas Aquinas's Scriptural commentaries, where one discovers the richest explication of the Christian's ordination as priest through incorporation into Christ. In his commentary on II Corinthians, for example, Aquinas-like his predecessors-draws on the typology of the Old Testament to illustrate the great grace received by believers. Taking

18 M. Morard, "Sacerdoce du Christ et sacerdoce des chrétiens dans le Commentaire des Psaumes de saint Thomas d'Aquin," pp. 132-142.

19 J.-P. Torrell, “The Priesthood of Christ," p. 136.

20 G. Berceville, "Le sacerdoce du Christ," p. 144; See also F. Ryan, “Thomas Aquinas and the Priesthood of all the Believers," pp. 143-148.

21 J.-P. Torrell, "The Priesthood of Christ," p. 136 note 21.

22 L. Elders, “The Presence of the Church Fathers in Aquinas' Commentaries," in Reading Sacred Scripture with Thomas Aquinas, p. 257.

23 Thomas Aquinas, ST III q. 8, a. 1.

24 Thomas Aquinas, ST III q. 63, a 3, c. In another systematic treatise, the De regno, Aquinas observes, "a royal priesthood is derived from him, and what is more, all those who believe in Christ, in so far as they are His members, are called kings and priests." De regno I, 15 ph. 109. 
after Chrysostom, Aquinas highlights the anointing of the Holy Spirit, and, like Augustine, he employs the language of the body sharing in the gifts of the head. Commenting on Hebrews, St. Thomas expounds,

We are in Christ in two ways, namely, by grace and by glory: by grace, inasmuch as we have been anointed with the grace of the Holy Spirit and made members of Christ and joined to him; by which grace Christ as man was also anointed ... And from the fullness of that anointing it has overflowed to all of us as "the precious oil on the head," namely of Christ, "has flowed down on the beard, the beard of Aaron" (Ps 133:2). Therefore, [Paul] says that "he who has anointed us, is God." He anointed us, I say, as kings and priests: "you made them a kingdom and priests to our God" (Rev 5:10); "you are a chosen race, a royal priesthood, a holy nation" (1 Pet 2:9). ${ }^{25}$

From his exegesis of II Corinthians, Aquinas determines that, in baptism, the believer is both anointed with the grace of the Holy Spirit and made a member of the Body of Christ. Joined to Christ, the Christian shares in every grace that Christ as man received, ${ }^{26}$ including participating in the triplex munera, the three offices of priest, prophet, and king.

When commenting on the Epistle to the Hebrews, Aquinas returns to the Christian's participation in the anointing of Christ. It is important to note that, like his contemporaries, ${ }^{27}$ Thomas attributed the composition of Hebrews to the apostle Paul. Subsequently, he interpreted Hebrews in the context of the single Pauline corpus. For Aquinas, the subject of the body of writings of Saint Paul was the grace of Christ, explored under different modes; ${ }^{28}$ "in the epistle to the Hebrews," Thomas writes, "he treats of this grace inasmuch as it pertains to the head, namely, Christ." 29

In a remarkable passage from his commentary on the letter to the Hebrews, Aquinas observes that, because Christ was anointed priest, prophet, and king,

25 Thomas Aquinas, Super 2 ad Corinthios chap. 1, lect. 5, no. 44.

26 Excepting, of course, the grace of the hypostatic union. ST III, q. 2.

27 F. Ryan, “Thomas Aquinas and the Priesthood of all the Believers," p. 135.

28 Aquinas wrote, "For he wrote fourteen letters, nine of which instructed the church of the gentiles; four, the prelates and princes of the church, i.e., kings; and one to the people of Israel, namely, the letter to the Hebrews. For this entire teaching is about Christ's grace, which can be considered in three ways: In one way, as it is in the Head, namely, Christ, and in this regard it is explained in the letter to the Hebrews. In another way, as it is found in the chief members of the Mystical Body, and this is explained in the letters to the prelates. In a third way, as it is found in the Mystical Body itself, that is, the Church, and this is explained in the letters sent to the gentiles." Super ad Romanos, Prol., no. 11.

29 Thomas Aquinas, Super ad Hebreos, Prol., no. 4. 
it also befits him to be anointed with the oil of holiness and gladness; for the sacraments, which are vessels of grace, were instituted by him ... This anointing also befits Christians, for they are kings and priests: "you are a chosen race, a royal priesthood" (1 Pet 2:9); "you have made us a kingdom and priests for our God" (Rev 3:10). Furthermore, he has the Holy Spirit, who is the spirit of prophecy: "I will pour out my spirit upon all flesh; and your sons and your daughters shall prophesy" (Joel 2:28). Therefore, all are anointed with an invisible anointing: "now he that has confirmed us with you in Christ and that has anointed us is God: who has also sealed us and given the pledge of the Spirit in our hearts" (2 Cor 1:21).

And Thomas concludes, "But what comparison is there between the anointed Christ and anointed Christians? This comparison, namely, that he has it principally and first, but we and others have it from him." 30

The theology that Aquinas develops is extraordinary, not least because it was developed in the thirteenth century. Drawing upon the wisdom garnered from years of meditation upon and commentary on the Scriptures, as well as the insights gained from the writings of the Fathers, Aquinas proposes an understanding of the baptismal priesthood that anticipates three of the conclusions of the Second Vatican Council. (1) Christ, the anointed one, grants us a share in his own anointing through the sacrament of baptism; the priesthood they possess by virtue of their membership in Christ is subordinate and participated. ${ }^{31}$ The believer, then, is said to be priest because Christ, first, is priest; for Thomas the members of the Body share the same office as their exalted Head. (2) The anointing the Christian receives is that of the Holy Spirit-imparted through the sacraments founded by Christ-who seals the believer, bestowing upon him the virtues, gifts, charisms, and, above all, grace, which is nothing less than a participation of the Divine nature. ${ }^{32}$ (3) Ordained through his incorporation into Christ's body, the believer is to live a life of holiness, worshiping the God whose nature he participated by the gift of grace; this is the topic of the second part of this paper.

In sum, we have seen that three great Doctors of the Church-Augustine, Chrysostom, and Aquinas-concur: the faithful are ordained by baptism, the anointing with the Holy Spirit, and through incorporation into the Mystical Body. While each Doctor articulates it in his own manner, there is no doubt

30 Thomas Aquinas, Super ad Hebreos, c. 1, lect. 4, no. 64-65. See F. Ryan, “Thomas Aquinas and the Priesthood of all the Believers: Aquinas' Commentary on the Epistle to the Hebrews," 144-148.

31 Thomas Aquinas, ST III, q. 22, a. 1, ad 3; See J.-P. Torrell, “The Priesthood of Christ,” 133.

32 Thomas Aquinas, ST II-II, q. 110, a. 3. 
that all hold that the believer-made one with Christ, their head-is himself ordained priest.

\section{Ordained to Worship: The Acts of the Baptismal Priesthood}

Augustine, John Chrysostom, and Thomas Aquinas all articulate that the believer, because he shares in Christ's priesthood, is ordered to particular acts which follow necessarily upon their ordination to the baptismal priesthood, namely acts of worship. They divide the acts of worship exercised by the baptismal priesthood into two general categories: (1) liturgical worship-particularly the Holy Sacrifice of the Mass-and (2) living a life of holiness in accordance with the vocation to which they have been called (Eph 4:1). In this section, I will first explore how Augustine and Chrysostom each articulates the acts of worship proper to the priesthood of the baptized. I will then consider Aquinas's own understanding and demonstrate how his teaching harmonizes with the doctrine of his predecessors.

\subsection{The Acts of the Baptismal Priesthood in Augustine: Works Performed in the Union of Charity}

As discussed in part one, Augustine envisions the faithful as made one with Christ the priest by their baptismal anointing; constituted as a priest, the believer is ordered to a particular function, namely to worship God through offering sacrifices in union with and in imitation of Christ. Countering the conception that martyrdom the only perfect imitation of Christ's sacrifice, the Bishop of Hippo rearticulates the definition of sacrifice, explaining that, "every visible sacrifice is a sacrament ... of the invisible sacrifice." ${ }^{33}$ For Augustine, then, "a true sacrifice [is] every work ... done that we may be united to God in holy fellowship, and which has a reference to that supreme good and end in which alone we [are] truly blessed." 34 When referenced to God, every exterior action manifests an interior outpouring of love for God, rendering the offering a true sacrifice. The whole of the Christian life, then, becomes a sacrifice of the baptized priest, the body serving as an instrument of his soul wherein the true sacrifice is offered. For, as Augustine contemplates, "how much more does the soul itself become a sacrifice when it directs itself to God so that, aflame with the fire of love for him, it loses the form of worldly desire and, now subject to him,

33 Augustine, civ. Dei X, 5 (PL 41:282).

34 Augustine, civ. Dei X, 6 (PL 41:283). 
is reformed to him as to an unchanging form, thus pleasing him by receiving its beauty from his beauty?" 35 Imbued with charity, every work of the baptized person can be a sacrifice rendered to God.

The liturgical work of the Church must likewise be inflamed with the love of God. As discussed above, Augustine understands each Christian as a member of the One Christ. For this reason, he affirms that the Body is always offered in union with its Head: "the congregation and fellowship of the saints are offered to God as a universal sacrifice through the great High Priest, who, in his passion, offered himself to God for us in the form of a servant, to the end that we might be in the body of such a great head." ${ }^{36}$ For Augustine, this is supremely true with respect to the Holy Sacrifice of the Mass, wherein Christ's sacrificial offering is commemorated. Augustine emphasizes that, in the Eucharist, it is not Christ alone who is presented to the Father, but Christ united with his Body, the Church. "This is the sacrifice of Christian: [who] although many, [are] one body in Christ. And this is the sacrifice that the Church continually celebrates in the sacrament of the altar (which is well known to the faithful), where it is made plain to her that, in the offering she makes, she herself is offered." 37 By the priesthood in which they participate as a member of Christ's Body, the Church, the faithful re-presents the Eucharistic sacrifice to God, offering to the Father the perfect Victim and themselves along with Him.

According to the Bishop of Hippo, every virtuous action of the believer, inasmuch as he is united with the Church, becomes a priestly act of sacrificial worship rendered to God. Living a life of holiness, the baptized priest renders to God the service owed through latria:

For we are all collectively his temple and individually his temples, since he deigns to dwell both in the concord of all and in each individual ... Our heart, when lifted up to him, is his altar. It is with his only-begotten Son as our priest that we propitiate him. To him we sacrifice bleeding victims when we fight for his truth to the point of shedding blood. We honor him with the sweetest incense when, in his sight, we burn with devout and holy love. To him we vow and return both his gifts in us and our very selves ... To him we offer, on the altar of the heart, the sacrifice of humility and praise, kindled by the fire of love. ${ }^{38}$

35 Augustine, civ. Dei X, 6 (PL 41:283-4).

36 Augustine, civ. Dei X, 6 (PL 41:284).

37 Augustine, civ. Dei X, 6 (PL 41:284).

38 Augustine, civ. Dei X, 3 (PL 41:280). 
Augustine understands the harmony that exists between the sacrifice offered at Mass and the sacrifice offered in the daily life of the Christian. For, the baptized priest, united to Christ and to the Church, offers himself both on the altar at the Eucharist and on the altar of his heart through any action referenced to God as his supreme good.

\subsection{The Acts of the Baptismal Priesthood in Chrysostom: A Priesthood of Mercy}

As the Patriarch of Constantinople, John Chrysostom exhorted the faithful to respond to exercise their priesthood in accordance with the great gifts they received in baptism. Like Augustine, Chrysostom recognizes that the baptismal priesthood is exercised in both liturgical sacrifice and the sacrifice of a virtuous life. Liturgically, the faithful priests render worship in union with the whole Body, which is led by and represented in the person of the ministerial priest. Indeed, Chrysostom teaches, "in the most awe-filled mysteries themselves, the priest prays for the people and the people also pray for the priest... The offering of thanksgiving again is common: for neither does [the minister] give thanks alone, but also [with] all the people." ${ }^{39}$

For John Chrysostom, however, it is the second category of worship, the sacrifice of a holy life, that constitutes the principal acts for which the baptized priest is ordained. The Christian priest must exhibit a life worthy of the gift he has received. ${ }^{40}$ As the Patriarch of Constantinople preached to his congregation, "we ought to understand our whole life as serving and ministering. And this will be so, if every day you bring Him yourself as a sacrifice and become the priest of your own body, and of the virtue of your soul." ${ }^{11}$

The priestly life consists of willingly imitating Christ's example of holiness, practicing the works of mercy toward the members of Christ's Body on earth. Preaching on the Gospel of Matthew, Chrysostom exhorts his congregation, saying:

Consider, you have become a priest of Christ, giving with your own hand, not flesh but bread, not blood but a cup of cold water. He clothed you with a garment of salvation, and He clothed you by Himself; so you ought to at least clothe Him by your servant. He made you glorious in Heaven, you ought to deliver Him from

39 John Chrysostom, Hom. in II Cor. 18.3 (PG 61:527).

40 John Chrysostom, Hom. in II Cor, 3.7 (PG 61:418).

41 John Chrysostom, Hom. in Rom. 20.1 (PG 60:597); See Nocent, "Il sacerdozio dei fedeli secondo Giovanni Criosotomo," 319-323. 
shivering and nakedness and shame. He made you a fellow citizen of the angels, you then must give Him at least the covering of your roof." 42

Chrysostom even insists that, by the practice of almsgiving, the merciful man exercises his priesthood. Although this priest is "not arrayed in a robe reaching to the feet, nor does he carry about bells, nor wear a crown ... he is wrapped in the robe of loving-kindness, [one] holier than the sacred vestment; and [he] is anointed with oil, not composed of material elements, but produced by the Spirit, and he bears a crown of mercies." 43

Chrysostom explains that the locus of sacrifice for the baptized priest is his neighbor toward whom he acts mercifully on account of his neighbor's union with Christ. The Patriarch of Constantinople proclaims that in works of charity, "the body of the Lord is made your altar." ${ }^{44}$ Moreover, Chrysostom chastises those who neglect their vocation as priests, worshiping God in church yet not exercising mercy to their neighbor. He urges them to conversion, preaching,

You honor this altar [of stone] because it receives Christ's body; but you treat him that is himself the body of Christ with derision, and when he is perishing, with neglect. This altar you may see lying everywhere ... and [you] could sacrifice upon it every hour ... As the priest stands invoking the Spirit, so ought you also invoke the Spirit, not by speech but by deeds ... indeed, you are silent, but your work speaks: and a sacrifice of praise is made, with no heifer slain nor hide burnt, but with a spiritual soul presenting her proper offering. ${ }^{45}$

For Chrysostom, the imperative of mercy toward one's neighbor obliges every member of the priesthood of the faithful. Liturgical worship and worship by the sacrifice of mercy must be harmonious, following from the same principle of charity. Indeed, preaching on Christ's injunction to "leave your gift at the altar and reconcile with your brother," the Patriarch of Constantinople puts the following on the lips of Christ, "Let my service be interrupted, that your love may continue; since this too is a sacrifice, your being reconciled to your brother." ${ }^{\prime 6}$ For Chrysostom, the primary impetus is toward the continuation of love: all priestly sacrifice then, whether liturgical acts or works of mercy, must be rendered as worship to God in charity.

\footnotetext{
42 John Chrysostom, Hom. in Matth. 45.3 (PG 58:474-5).

43 John Chrysostom, Hom. in II Cor 20.3 (PG 61:539).

44 John Chrysostom, Hom. in II Cor 20.3 (PG 61:540).

45 John Chrysostom, Hom. in II Cor 20.3 (PG 61:540).

46 John Chrysostom, Hom. in Matth. 16.12 (PG 57:251).
} 


\subsection{The Acts of the Baptismal Priesthood in Aquinas: A Priesthood in the Order of Faith and Charity}

In treating the themes associated with the priesthood of the baptized, Aquinas's thought is reminiscent of both Augustine and Chrysostom. Like his predecessors, Aquinas holds the exercise of the baptismal priesthood is not limited to liturgical worship but also includes acts of virtue. Indeed, Aquinas explicitly follows Augustine, affirming that "any work done that we may cleave to God in holy fellowship." ${ }^{47}$ Therefore, every action of the baptized priest is an act of worship in service to God.

Augustine's definition of sacrifice as "every visible sacrifice is a sacrament, that is a sacred sign, of the invisible sacrifice" 48 is also adopted by Aquinas, who makes it a keystone of his theology. Used by Aquinas particularly in reference to Christ's priestly sacrifice on the Cross, ${ }^{49} \mathrm{St}$. Thomas also applies it to the sacrifices $^{50}$ offered by those in union with Christ, both in the liturgy and through a life of charity.

For the Doctor Communis, the liturgical dimension of the Christian's worship is encapsulated in his teaching on the sacramental character received in baptism. Recall that the baptismal character deputes the believer to the worship of God, specifically through participation in the sacramental life of the Church. The liturgical worship offered by the baptized priest differs from that of the ministerial priest, in that, by the character of Holy Orders, the ministerial priest stands in persona Christi and has the power to confect the sacraments. Nevertheless, Aquinas teaches, the baptized priest, "united with Christ by spiritual union through faith and charity ... has a spiritual priesthood for offering spiritual sacrifices." ${ }^{11}$ These spiritual sacrifices include the Eucharist, which is the spiritual sacrifice of the Church. ${ }^{52}$ The mode of offering is distinct from that of the ministerial priest, yet the offering made in the intellect and will of the baptized is no less integral to the work of his own sanctification nor to that of building up the Body of Christ, the Church. ${ }^{53}$

The baptismal priest is also ordained for the offering of the spiritual sacrifices that pertain to a holy life. This is particularly evident in Aquinas's em-

\footnotetext{
47 Thomas Aquinas, ST II-II. emphasis added. Cf. Emery, "Le sacerdoce spirituel," 230.

48 Augustine, civ. Dei X, 6; see note 23.

49 Thomas Aquinas, ST III, q. 22, a. 2 c.

50 Thomas Aquinas, ST III, q. 60, a. 1, s.c.

51 Thomas Aquinas, ST III, q. 82, a. 1, ad 2.

52 Thomas Aquinas, Cf. ST I-II, a. 4, ad 3; Super ad Hebreos, c. 5, lect. 1, 255.

53 Thomas Aquinas, ST III, q. 63, a. 3, ad 3.
} 
ployment of the Opus imperfectum in Mattaeum, a work incorrectly attributed to Chrysostom in the medieval era. Pseudo-Chrysostom teaches that "all the saints are priests," 54 a quotation that appears in multiple works of Aquinas. Although this text does not properly belong to the Chrysostom corpus, Aquinas's treatment of it regarding the baptismal priesthood demonstrates the Angelic Doctor's fidelity to Chrysostom's thought and therefore gives this quote particular relevance for our study.

Although pseudo-Chrysostom's words are used as objections in the Sum$m a$, Thomas's earlier work in the Sentences demonstrates a fuller understanding of the priesthood of the baptized, or, as he prefers, the spiritual priesthood of the just. For Aquinas, the exercise of the priesthood of the just nothing more than living out the graces received in baptism to the fullest, with the Christian offering himself to God in charity. In book 4, distinction 13, he writes, "Every good man can be called a priest mystically (sacerdos mystice) since he offers to God a mystical sacrifice by offering himself to God, namely 'as a living sacrifice to God' (Rm 12, 1)." 55 Later, Aquinas clarifies, "Chrysostom takes the name of priest as to the interpretation of the name, according as 'sacer-dotal' means 'giving sacred things.' For then any just person, to the extent that he gives sacred merits to help someone, has this interpretation of sacerdotal." 56

Therefore, Aquinas is clear that the sacramental character orders the believer to the priestly worship of God in union with Christ, and the spiritual priesthood denotes a priesthood not in the sacramental order, but in the order of faith and of charity. ${ }^{57}$ This priesthood is offered, first through the oblation of one's self to God, and secondly, by giving "sacred merits" out of mercy for one's neighbor. For St. Thomas, then, the priesthood of the just belongs to all who are baptized and who live their baptismal graces to the fullest, exercising charity toward God and neighbor.

Aquinas is clear that the exercise of charity must be comprised of both an interior and exterior aspect, with the interior being principle. As to the interior sacrifice, Thomas writes, "of all man's goods, God specially accepts that of the human soul when it is offered to Him in sacrifice." ${ }^{38}$ However, the exterior sacrifice, to be a genuine sacrifice, must always be rooted in the interior oblation, as the Doctor Communis explains, writing "the sacrifice that is offered outwardly represents the inward spiritual sacrifice, whereby the soul offers itself

\footnotetext{
54 Thomas Aquinas, ST III, q. 82, a. 1, obj 2.

55 Thomas Aquinas, IV Sent., d. 13, q. 1, a. 1, q la $^{\text {1, }}$ arg. 1.

56 Thomas Aquinas, IV Sent., d. 24, q. 1, a. 3, q q $^{\text {la }}$, ad. 1.

57 Thomas Aquinas, III Sent., d. 31, q. 1, a. 4, q $\mathrm{q}^{\text {la }} 1$, arg. 2.

58 Thomas Aquinas, ST II-II, q. 182, a. 2, ad 3.
} 
to God;" 59 and, again, "external sacrifice is representative of true, interior sacrifice, by which the human mind offers itself to God." ${ }^{60}$ Exterior sacrifices rendered in charity are meritorious, then, precisely because of the interior offering rendered to God.

The exterior sacrifices of charity performed by the baptismal priesthood consist primarily in the works of mercy that aim to alleviate the deficiencies of one's neighbors. ${ }^{61}$ Aquinas is clear that the spiritual sacrifices of mercy are more acceptable to Him than burnt offerings or other cultic sacrifices, precisely because of the acts of mercy aid those in need. He expounds, "It is not for God's sake that we worship Him with exterior sacrifices and gifts ... For He does not need our sacrifices, but instead He wants them to be offered for the sake of our devotion and for the sake of the advantage of our neighbors." 62 Therefore, just as Chrysostom before him, Thomas counts among the sacrifices of the spiritual priesthood the corporeal and spiritual works of mercy, for, with Augustine, he holds a true sacrifice consists of "any work done that we may cleave to God in holy fellowship." 63

\section{Conclusion}

In the final analysis, it is evident that Aquinas's understanding of the baptismal priesthood bears the marks of influence by both Augustine and Chrysostom. Drawing upon these great authorities, one from the West and the other from the East, Aquinas incorporates their teachings into his own theological vision, not simply repeating their ideas but making them his own. This is true not only within his treatment of the ordination to the common priesthood through the sacrament of baptism and incorporation into Christ but also in his treatment of the exercise of the baptismal priesthood in offering sacrifice.

Aquinas's theological vision harmonizes with Augustine and Chrysostom. All three theologians understand the exercise of the priesthood of the baptized to consist both in the offering of liturgical sacrifices-particularly participation in the Eucharist-as well as sacrifices offered by a heart overflowing with love of God and neighbor. These doctors outline that which the Fathers of the Second

\footnotetext{
59 Thomas Aquinas, ST II-II, q. 85, a. 2, c.

60 Thomas Aquinas, SCG III, 120.

61 Thomas Aquinas, ST II-II, q. 32, a. 2, ob. 4.

62 Thomas Aquinas, ST II-II, q. 30, a. 4, ad 1.

63 Thomas Aquinas, ST II-II, q. 85. a. 3, ob. 1.
} 
Vatican Council later encapsulated in dogma: ${ }^{64}$ that the believer is ordained to dignity of priest through baptism; that he exercises his baptismal priesthood for his sanctification and that of his neighbor; and that, because of his interior union with God through faith and charity, his every action serves to worship God and to redound to His greater glory.

\section{References}

Augustine of Hippo. City of God [civ. Dei], WSA I.6-7, New York 2013.

Augustine of Hippo. Explanations of the Psalms [en. Ps.], WSA III.20, New York 2004. Augustine of Hippo. On the Soul and Its Origin [an. et or.], WSA I.23, New York 1997. Augustine of Hippo. Sermons, WSA III.3, New York 1991.

Augustine of Hippo. Tractates on John [Jo. ev. tr.] NPNF1-VII, Peabody MA 2004.

Berceville, G. "Le sacerdoce du Christ dans le Commentaire de lépître aux Hébreux de saint Thomas d'Aquin," Revue Thomiste 99 (1999): 143-158.

Chenu, M.-D., Toward Understanding Saint Thomas, Chicago 1964.

Dabin, P., Le sacerdoce royal des fidèles dans les livres saints, Paris 1941.

John Chrysostom. Homilies on the Gospel of John, NPNF1-XIV, Peabody, MA 2004.

John Chrysostom. Homilies on Colossians, NPNF1-XIII, Peabody, MA 2004.

John Chrysostom. Homilies on the Epistles of Paul to the Corinthians, NPNF1-XII, Peabody, MA 2004.

John Chrysostom. Homilies on Romans, NPNF1-XI, Peabody, MA 2004.

John Chrysostom. Homilies on the Gospel of Matthew, NPNF1-X, Peabody, MA 2004.

Elders, L., "The Presence of the Church Fathers in Aquinas' Commentaries on the Gospel of Matthew and the Gospel of John," pp. 257-286 in P. Roszak and J. Vijgen, eds., Reading Sacred Scripture with Thomas Aquinas: Hermeneutical Tools, Theological Questions, and New Perspectives, Turnhout, Belgium 2015.

Elders, L., Thomas Aquinas and His Predecessors: The Philosophers and the Church Fathers in His Works, Washington, DC 2015.

Emery, G., "Le sacerdoce spirituel des fidèles chez saint Thomas d'Aquin," Revue Thomiste 99 (1999): 211-43.

Morard, M. "Sacerdoce du Christ et sacerdoce des chrétiens dans le Commentaire des Psaumes de saint Thomas d'Aquin," Revue Thomiste 99 (1999): 119-142.

Nocent, A., "Il sacerdozio dei fedeli secondo Giovanni Criosotomo." Vetera Christianorum 7 (1970): 305-324.

Roszak, P. and J. Vijgen, eds., Reading Sacred Scripture with Thomas Aquinas: Hermeneutical Tools, Theological Questions, and New Perspectives, Turnhout, Belgium 2015. 
Ryan, F., "Thomas Aquinas and the Priesthood of all the Believers: Aquinas' Commentary on the Epistle to the Hebrews," Biblica et Patristica Thoruniensia 9 (2016): 133-148.

Ryan, L., "Patristic Teaching on the Priesthood of the Faithful." Irish Theological Quarterly 29 (1962): 25-51.

Thomas Aquinas. De regno, Lander, WY 2018.

Thomas Aquinas. Summa Contra Gentiles III \& IV, Lander, WY 2019.

Thomas Aquinas. Summa theologiae, Lander, WY 2012.

Thomas Aquinas. Super 2 ad Corinthios, Lander, WY 2012.

Thomas Aquinas. Super ad Hebreos, Lander, WY 2012.

Thomas Aquinas. Scriptum Super Sententiis III, https://aquinas.cc/16/16/ 2

Thomas Aquinas. Scriptum Super Sententiis IV, Lander, WY 2017.

Torrell, J.-P., "The Priesthood of Christ in the Summa Theologiae" in Christ and Spirituality in St. Thomas Aquinas. 126-158. Washington, DC 2011.

William of Tocco, Ystoria sancti Thome de Aquino de Guillaume de Tocco (1323): édition critique, introduction et notes, Toronto 1996. 